\title{
Die weg van die Here in die woestyn oftewel God se grootpad in die wildernis: Oor A Story of two Ways
}

J A Loader

\section{ABSTRACT}

The Lord's way in the desert or: God's highway in the Wilderness. On A Story of two Ways

This paper contends that the history of the study of the Old Testament in South Africa, written by Professor $J H$ le Roux, is a very important work, although flawed in certain respects. It is argued that the author himself reads his texts too 'immanently', that he paints static portraits of scholars while discarding development, that an either-or picture is drawn in which such overriding concern for an 'immanent'-historical opposition is manifested that the result is an oversimplified presentation with apologetic overtones, and that the criteria for inclusion in the book are applied arbitrarily.

1 Prolegomenon

Subseksie I: Teks

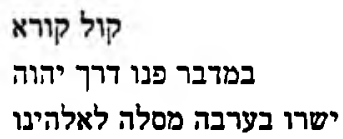

(Jes 40:3)

Subseksie 2. I: Histories-struktureel (Westermann)

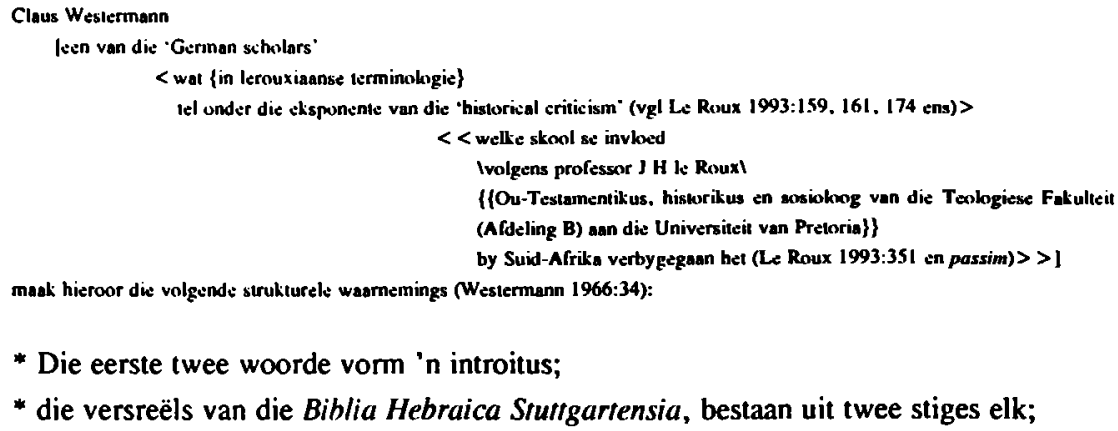

* Die eerste twee woorde vorm 'n introitus;

* die versreëls van die Biblia Hebraica Stuttgartensia, bestaan uit twee stiges elk;

\footnotetext{
I 'n Beroep op die leser: Hierdie artikel se slotparagraaf moet eerste gelees word.

Vanweë die aard van die resensie-artikel word afgewyk van die normale verwysingsisteem van Skrif en Kerk.
} 
* hierdie vier reëls beslaan twee heffings elk;

* die parallelisme, die klem en die ritme bevestig die verbinding van hierdie eenhede;

* die genoemde strukturele elemente verhoed die verbinding van קול קורא met

* die Septuaginta se vertaling, gevolg deur die Evangelies (Mt 3:3 par), gee die struktuur en dus die betekenis verkeerd weer.

\section{Subseksie 2.2: Uitbreiding}

Hiervolgens moet moet daar dus in die wildernis 'die' weg van Jahwe berei word en in die woestyn "'n' grootpad vir onse God gelyk gemaak word. Die groot vraag is nou: Word hier van een pad of van twee paaie gepraat? Is 'n weg en 'n grootpad dieselfde? Hiervoor is die status determinatus van דרך teenoor die onbepaaldheid van מסלה nie van betekenis nie, aangesien eersgenoemde in die status constructus staan en dus bepaald moet wees. As 'Jahwe' in hierdie struktuur dieselfde is as 'onse God', wat niemand sal bestry nie, dan moet 'woestyn' en 'wildernis' dieselfde wees en 'berei' moet parallel staan aan 'gelyk maak'. Dan bly net een konklusie oor: die stilistiek van die passasie toon dat hier slegs van een pad sprake is en nie van twee weë nie. Dit afgesien daarvan dat Westermann uitgebreide aandag skenk aan die historiese aspek van die 'total context' van die profetiese spreker, sy Joodse aanhoorders in Babel en die godsdienshistoriese verskynsel van die Babiloniese prosessies by geleentheid waarvan die Babiloniërs grootpaaie vir die intog van hulle gode gelyk gemaak het. Net een pad - ten

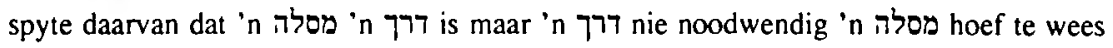
nie. So bevestig die stilisties-strukturele analise van die histories-kritiese leerling van Gerhard von Rad (vgl Le Roux 1993:159), aan wie Westermann se kommentaar dan ook opgedra is, dit wat ons uit die historiese 'total context' weet: die Babiloniërs het net een pad per prosessie gemaak. Gaan mens stilisties-struktureel én histories met die teks om, dan vind jy uit daar is net een weg, nie twee nie.

2

Inleiding

\section{Subseksie 1: Antisipasie}

So kan daar ook 'n vraagteken oor professor Le Roux se 'two ways' geplaas word. Een van sy דרד דרכים is 'n blote מרך, bewandel deur 'n hele prosessie afgodspriesters, en die ander is 'n ware grootpad, 'n מסלה, die weg van die Here self (let wel, status constructus) wat penreguit deur die Suid-Afrikaanse woesteny na Sion lei, tans, meer as 'n eeu ná die eerste stem roepende in die wildernis van die Suidland (soos die Septuaginta ten onregte, sê Westermann, die introitus en die eerste reël van ons teks verbind), bewandel deur slegs een profeet agternageloop deur 'n handjievol profeteseuns. 
Professor Le Roux verwyt Adrianus van Selms dat hy met the historical method' die spot dryf (Le Roux 1993:178-179). Hy self spot egter ook met kollegas. Wanneer hy byvoorbeeld van sy professoregenoot (mens kan nie 'medeprofessor' vir 'n volle sê nie) aan die Universiteit van Pretoria se werk aan die Psalms praat, gee hy aan die paragraaf die opskrif 'Sing unto the Lord in a structured manner'. Die spot met Prinsloo se manier om die draadwerk van alle psalms met 'n streepnetwerk te anatomiseer, spreek duidelik hieruit. Dieselfde kan deur die leser ervaar word as die outeur tot vervelens toe vertel watter onmisbare bydrae $X$ of $Y$ gelewer het en hulle dan deur die struktuur van sy inordening relegeer tot betekenisloosheid of deur kontekstualisering daarvoor sorg dat niemand kan raaksien wat so 'extremely/very important' aan die bydrae is nie. Dit is moontlik en selfs waarskynlik dat professor Le Roux se 'amicable personality', 'n hoedanigheid waarvoor hy 'n ander kollega prys, as skild teen sulke kritiek voorgehou kan word. Sy goedhartigheid staan buite kyf, maar professor Le Roux se geaardheid en (moontlike) bedoeling neem nie weg wat hy gedoen het nie. Sy boek bevat iets onmiskenbaar skerps. Daar is ' $n$ duidelike ondertoon van skerpte in sy manier om kollegas so oordadig te prys dat matige lof die ekwivalent van geen lof word en blote konstatering van wat iemand gedoen het 'n suggestie dat professor Le Roux aan niks goeds kon dink om daarvan te sê nie. Geen leser kan daarvoor verkwalik word as hy of sy die outeur van spot verdink nie. Dié wat hom nie ken nie, kan die inflasionêre lofstyl 'een belachelijke zaak' vind (Frankena 1969:79 oor Van Selms, met instemming aangehaal in Le Roux 1993:179). Selfs dié wat hom ken, mag begin wonder of die 'amicable' styl nie 'n veiligstelling vir fyn spot is nie; goedhartigheid hoef immers nie stomp te wees nie. Alternatiewelik roep die oordadige styl 'n groteske beeld van die Suid-Afrikaanse Ou-Testamentiese wetenskap op. Daaroor meer hieronder.

Daarmee gee ek nie te kenne dat dit onvanpas of onbillik is of dat dit nie in 'n akademiese publikasie tuishoort nie. Inteendeel, ' $n$ historikus het ewe veel reg daarop as wat die leser het om dit op te merk. Ek verantwoord maar net wat Jesaja 40 met die inleiding tot 'n kritiese bespreking van professor Le Roux se betekenisvolle bydrae tot die Suid-Afrikaanse vakliteratuur te doen het. Van Selms het immers gesê dat 'n akademiese publikasie geen verskoning is om flou te wees nie, en Wilhelm Gesenius het behae daarin geskep om Heinrich Ewald, die 'Göttinger Prophet', se siel uit te trek wanneer hy sy werk bespreek, terwyl iets soortgelyks ook by Eduard Reuss en Karl Heinrich Graf te sien is (vgl Kraus 1969:245-246, Vincent 1990:140). lets wat in SuidAfrika weens die subsidiestelsel nie juis gebruiklik is nie. 
Ná 'n inhoudsopgawe volg 'n voorwoord van die reeksredakteur waarin eers die kriteria vir insluiting in die boek uit die daaropvolgende proloog en dan die daaraanvoorafgaande inhoudsopgawe self opgesom word. Reeksvoorwoord en proloog word geskei deur 'n outeursvoorwoord waarin 'n serie dankwoorde uitgespreek word. Dié is noukeurig gestruktureer en word, soos in die geval van die bekende hangbrugstruktuur van die Onse Vader (indien die doksologie bybereken word ${ }^{2}$ ), aan weerskante deur twee ankerpunte gestut (Deist en God), terwyl die middel afhang by die taalversorgster wat 'n hele aantal krummels en korsies van haar daaglikse brood onversorg gelaat het. Die proloog self makk effektiewe gebruik van die pluralis majestatis (wat nie lekker sit op 'n Amerikaanserige kuier-hebbelikheid waarin met noem- en byname na vakgenote verwys word nie) en verduidelik dat die boek 'a history and not a chronicle' is (Le Roux 1993:12 supra) terwyl dit wel 'something of a chronicle' is (Le Roux 1993:12 infra). Myns insiens is dit 'n goeie tipering van die werk, soos hopelik hieronder sal blyk. Verder word die name genoem van 'n aantal 'important scholars' wat, ten spyte van hulle 'very important work', die boek slegs skrams gehaal het of, soos die Satan in die boek Job, dit net tot in die proloog gemaak het (Le Roux 1993:13)3. Vervolgens sluit die proloog met 'n opsomming van die boek self (Le Roux 1993:13-15), wat 'n effektiewe ringkomposisie met die epiloog (Le Roux 1993:350-353) vorm, hoewel in laasgenoemde geval nie van ' $\mathrm{n}$ inhoudsopsomming sprake is nie.

Ons het hier te make met 'n baie belangrike stuk navorsing waarin vir die eerste keer in die geskiedenis 'n geskiedenis van die Suid-Afrikaanse hantering van die Ou Testament gebied word. Die sterk punt daarvan is na my mening nie die landsvlagvormige beeld van 'n vurkpad wat die outeur by die leser skep nie, maar sy talryke opsommings van geselekteerde werke van geselekteerde Ou-Testamentici. Die kroniekkarakter van sy boek - wat hyself uitwys in weerwil daarvan dat hy dit nie heeltemal so wou gehad het nie - strek verder as die periferiese verwysing na sommige vakgenote; dit sluit ook die opsommings en soms uitvoerige weergawes van talle artikels en boeke in. Hoewel heelwat natuurlik nie opgesom word nie, is dit al klaar 'n rede waarom die aankoop van die boek aanbeveel behoort te word: nog nooit in die geskiedenis van Suid-Afrika is soveel werke van soveel vakgenote in so min bladsye gekondenseer nie. Die boek word 'n nuttige verwysingsbron om vinnig na te gaan wat die essensie (en selfs meer) van geselekteerde Suid-Afrikaanse werke oor die Ou Testament is. Ek voorspel dat Suid-Afrikaanse navorsers en studente die boek reeds om hierdie rede baie

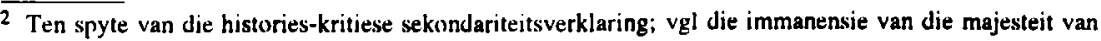
God in die wereld (שכינה ens).

${ }^{3}$ Hoewel daar ook diegene is wat net tot in die voorwoord gekom het en ander wat uit beide voorhowe afwesig is.
} 
behulpsaam sal vind.

Ironies lê ' $n / d i e$ swak punt van die boek ook hier (op die gevaar af dat ek deur dit te sê die idee van die skrywer mag versterk dat ek te lief is vir polêre spanninge; vgl Le Roux 1993:317, 319). Ten spyte van die passie van ons geskiedskrywer vir sy 'cause', word die boek nie net 'n massiewe versameling inligting nie, maar sluit dit ook baie detail in wat nie funksioneel vir die skrywe van ' $n$ geskiedenis is nie. Byvoorbeeld:

Fensham se opvattinge oor Ou-Testamentiese tekste teen die agtergrond van die Ou Nabye Ooste, die verskillende verbonde en die wetlike materiaal word bladsye lank tot op molekulêre vlak uitgespin (Le Roux 1993:119-140); die fynste detail oor waar Pentateugnarratiewe te vinde is, word op Deist se voetspoor nagesê (Le Roux 1993:167-169); rye en rye syfers bied die leser geleentheid om na te spoor waar Van Selms watter name vir die 'Pentateugouteur' gebruik het (Le Roux 1993:183); gedetailleerde hoeveelhede gegewens word beskikbaar gestel oor die Garrungen van die boek Prediker (Le Roux 1993:320); volledige tabelle (blykbaar meganies gereproduseer, hoewel geen erkenning aan die uitgewers gegee word nie) is byderhand met besonderhede wat nie vir 'n geskiedenis van die vakgebied nodig is nie, maar wel kan help wanneer iemand die detail van ' $n$ besondere Bybelboek bestudeer en die betrokke literatuur nie in die hande kan kry nie (bv Le Roux 1993:311, 321-322), en so aan. Die skrywer het nie al hierdie (en soortgelyke) detail nodig om wat hy wil sê, te onderbou of selfs te illustreer nie.

Hiermee gepaard gaan ook ' $n$ geweldige hoeveelheid herhaling. Nie alleen word keer op keer vertel hoe 'excellent' of 'important' ' $n$ indiwidu se werk is nie, maar dieselfde storie kom hoofstuk na hoofstuk aan die beurt (daarom, miskien, 'n 'story of two ways'). Telkens kom die skrywer met die bekendmaking dat dit mode was om teen die historiese kritiek gekant te wees en telkens openbaar hy dat daar twee skole teenoor mekaar te staan gekom het. Wat ons by die Pentateug gehoor het, hoor ons weer by die profete én by die Psalms én by die wysheid. As dit werklik so stereotiep daaraan toegegaan het, is daar nog minder rede om sulke uitvoerige opsommings oral in die boek in te werk - net om elke keer by dieselfde storie uit te kom. Om byvoorbeeld op die 277ste en 279ste bladsye die nuus gebreek te kry dat Prinsloo van die histories-kritiese metode weggebreek het, groot invloed op sy studente gehad het en jou werklik teenoor die historiese benadering ' $n$ 'immanent reading' gaan stel het, is net te veel. Nadat ons dieselfde boodskap hoofstukke lank ingeprent is, is ons al so afgestomp daarvoor dat dit allesbehalwe 'striking' is ( $\mathrm{vgl}$ Le Roux 1993:277).

Ek het nou geleidelik oorbeweeg van opmerkings met ' $n$ inleidende karakter na 'n meer resensiewe karakter, sodat die lasplek tussen die twee nie so maklik raak- 
gesien kan word nie. Daar is egter nog iets wat inleidend van aard opgevat moet word inleidend ten opsigte van meestal dié dele hieronder waar ek met verwysing na my eie werk reageer. Dit sal voorkom of ek my eie opvattinge teenoor die historiograaf verdedig. Ek doen dit nie om die onthalwe van verdediging alleen nie, maar ook ter wille van my betoog self. Ek kan nie my reaksie motiveer as ek dit nie substansieer nie. Professor Le Roux het my so 'n prominente plek in sy geskiedenis gegee en allerlei mooi dinge gesê, maar wat hy gedoen het, is na my beskeie mening ook nie bo kritiek verhewe nie. Daarom kan dit nie anders as dat my eie werk in die bespreking hieronder figureer nie. Uiteraard kan ek my argument ook beter ten opsigte van my eie werk as ten opsigte van ander s'n beredeneer. Ek meen egter dat wat ek só betoog, ook onderbou sal verskaf vir bespreking van die behandeling wat ander kollegas ontvang-

\section{'N ONIISTORIESE GESKIEDENIS}

Een van die vernaamste kritiekpunte wat teen Two Ways ingebring kan word, is dat die outeur daarvan byna deurgaans nalaat wat hy self propageer, naamlik respek vir die historiese perspektief. Die 'context' of 'total context', wat volgens hom so belangrik is in die (historiese) studie van die Ou Testament, word net soms en vaag en in die algemeen in berekening gebring, terwyl van historiese ontwikkeling so goed soos niks gemaak word nie.

\subsection{Die 'inınıanente' lees van tekste}

Professor Le Roux lees sy tekste 'immanent'. Soos historici geleer word, werk hy uit $\left(\mathrm{die}^{4}\right)$ 'primêre bronne'. Een van dié bronne waaraan hy uitvoerig aandag gee, is my monografie oor Qohelet (Loader 1979), wat hier as voorbeeld sal dien.

Ná gedetailleerde immanente beskrywings en reproduksies van wat in dié boek staan, maak hy die volgende uitspraak: "By the time he reaches the "last step" concerning "the examination of the historical perspectives" definite conclusions have already been reached. The rest is just an addendum (although important) to what has already been said about Qohelet's thought pattern' (Le Roux 1993:325). So 'frame' hy my in dieselfde skool as dié van Prinsloo, oor wie hy soortgelyk oordeel (Le Roux 1993:225). Waar kry hy die indruk dat ek alleen historiese perspektiewe ter sprake bring om my reeds ingenome standpunt te bevestig? - Alleen wit die teks van my boek. Hy het hom gelees soos hy daar staan, net die eindproduk. En ek verkwalik hom nie. Maar hy het die teks van Polar structures gelees om te kan sê wat hy wil laat pas by sy

\footnotetext{
${ }^{4}$ Heelwat 'primère bronne' word geignoreer of miskien selfs takties verswyg, waarcor hieronder nog een en ander sal blyk.
} 
opvatting van 'two ways' en om te sorg dat sy leser my net aan één kant van die bivurkasie raakloop.

Otto Kaiser, een van die leidende histories-kritiese Ou-Testamentici, en dan nog uit die geledere van die 'German scholars' wat so hoog by die outeur aangeskrewe staan, het die bock egter heeltemal anders gelees. In 'n artikel oor aspekte van die aanraking tussen Jodendom en Hellenisme warin hy werke sedert Ellermeier se bekende studie uit die sestigerjare (Ellermeier 1967) behandel (Kaiser 1982), gaan dit Kaiser oor die historiese bydrae van Polar structures. Hy sê:

'An dieser Stelle weniger mit der Interpretation des Kohelet als mit der Frage nach seiner Stellung im jüdischen Frühellenismus befaßt, reicht es aus positiv darauf hinzuweisen, daß Loader an einer ganzen Reihe bislang schwieriger Stellen überzeugende Deutungen gelungen sind' ... Schließlich wird es kaum Wunder nehmen, daß der Rezensent Loader in der Ansicht zustimmt, daß die Literarkritik (die lerouxiaanse 'historicalcritical' aspek) der literarischen Analyse (wat professor Le Roux strykdeur 'immanent reading' noem) nicht vorgreifen darf. Das ist ja auch letzlich in der alttestamentlichen Wissenschaft so nie geschehen, selbst wenn es in den Darstellungen so aussehen mag. Die Literarkritik setzt immer schon ein Verständnis des Textes, eine sorgfaltige Beobachtung seines Gedankenganges und der dabei sich ergebenen inhaltlichen Spannungen voraus' (Kaiser 1982:79).

Hierdie opmerkings is nie net insidenteel nie, maar deel van 'n betoog oor die historiese situering van Qohelet wat geld as dié aspek van my boek waarvoor Kaiser die meeste waardering het. Hy lees die hele monografie as ' $n$ betoog ter ondersteuning van die historiese inordening van Qohelet in die Israelitiese tradisie:

'Dabei (verwysend na my bespreking van die polêre spanninge wat vir kollega Le Roux blote 'strukture' is) gelingt es Loader von Einheit zu Einheit, die Verwurzelung des Weisen in der Tradition seines Volkes zu demonstrieren' (Kaiser 1982:78).

Vir Kaiser is die literêre studies in my boek nie net 'struktuuranalise' met 'just an addendum' wat my konklusies 'merely affirm' nie, maar 'n argument uit 'n noukeurige lees van die teks vir 'n geesteshistoriese plasing van Qohelet in die kultuur- en godsdienshistoriese omlysting van sy tyd. Soortgelyke opmerkings het Kaiser ook in 'n lesing van 1985 by die Universiteit van Suid-Afrika, waar professor Le Roux teenwoordig was, gemaak. 
Professor Le Roux hou net met sy eic lesing van my teks rekening en met niks daarrondom nie. Sy immanente lesing van my boek ${ }^{5}$ behoort egter op sigself al genoeg te gewees het om te sien dat iets met sy tipering fout is. In die konteks van my kritiek op die werk van Rainer Braun (Braun 1973) betoog ek juis dat wydreikende beweringe oor die herkoms en historiese verklaring van Qohelet se denke spesifiek met die 'actual thought patterns' dwarsdeur die boek onderbou moet word (Loader 1979:129). Wat ek daarmee gesê en bedoel het, is dat die destyds sogenoemde nuwe metode van lees juis materiaal vir die historiese verklaring kan bied. Ons geskiedskrywer se formulering verraai ook dat hy die skryfproses en die navorsingsproses verwar. 'By the time' dat ek my 'last step' bereik, sê hy, het ek reeds konklusies gevorm wat net gou deur die historiese perspektief bevestig moet word. In feite het ek toe reeds met die hipotese gewerk dat Qohelet vanuit die oud-Oosterse kultuur- en geesteshistoriese ontwikkeling verklaar moet word en probeer om dit uit die teks te motiveer. Die 'stappe' waarvan hier sprake is, is nie blote opeenvolgende rescpteboekstappe nie, maar aspekte of fasette wat logies onderskei en nie deurmekaargehaal moet word nie.

Professor Le Roux span ook histories die kar voor die perde. Die Afrikaanse weergawe van my boek was al in 1973 klaar - tegelyk met Braun s'n, sonder die 'struktuuranalises', en voordat ek nog selfs van W S Vorster se lesing (wat volgens ons outeur die algemene bekering tot 'immanente' lesing teweeggebring het ILe Roux 1993:27-28]) gehoor het. Ek het 'n studie van Qohelet gemaak waarin ek die eie aard van sy denke vanuit Griekse invloed probeer verklaar het (veral van Theognis, vgl Ranston 1925 passim; nog na te speur in my doktorale skripsie van 1970), maar in die gang van die navorsing het ek tot die oortuiging gekom dat dit onhoudbaar is en dat sy denke eerder uit die ontwikkeling van die Israelitiese wysheid self in die omlysting van die geskiedenis van die verwante kulture van die ou Nabye Ooste verklaar moet word. Vandaar my debat met Braun in die latere Engelse verwerking en die ondersteuning wat ek daarvoor van Kaiser gekry het. As daar van 'merely affirming' gepraat moet word, dan sou dit eerder my betoog oor die polêre strukture wees wat my historiese ondersoek bevestig as andersom. Die feit dat eersgenoemde veel meer bladsye as laasgenoemde beslaan, is toe te skryf aan die gedetailleerde betoogvoering. Professor Le Roux, lyk dit my, kyk immanent na die hoeveelheid bladsye en besluit dan dat dié aspek wat in die boek 'soos hy voor ons lê' die minderheid behaal, 'just an addendum' moet wees. In een van ons onderhoude tydens die skrywe van Two Ways het ek hom hierdie inligting gegee, maar hy het nie daarvan gebruik gemaak nie.

\footnotetext{
$\overline{5}$ En van ander van my geskrifte, sommige waarvan ek nog sal uitwys. $V_{g l}$ cok my kritiek op die struktuuranalitiese skcool se verwaarlosing van die historiese verbande van lekste en die positiwistiese tendense by die beoefenaars van die rigting (Loader 1982:97-98. 1989:1 32-133).
} 
Vervolgens ' $n$ voorbeeld wat deur die outeur onvermybaar gemaak word. Hy sê (Le Roux 1993:28): 'Perhaps one of the most important and influential articles that was ever written in our theological context came from the hand of Jimmie Loader (1978b:1-40)'. Voorwaar 'n groot woord, en dan nog vergesel van allerlei opmerkings or die enorme invloed wat ek hiermee uitgeoefen het (wat oral in Two Ways deurslaan). Die probleem is net dat ek nie so ' $n$ artikel geskryf het nie. In feite: niemand het nie. Professor Le Roux ken die geskiedenis van dié sogenaamde artikel en die 'total context' daarvan, maar verswyg dit desnieteenstaande. Al wat hy doen (Le Roux 1993:29), is ' $n$ feitelik onjuiste nota (kennelik later in sy manuskrip bygevoeg) dat 'Loader's article' die resultaal ('outcome') was van lesings wat ek in samewerking met professor J P Louw in die Departement Semitiese Tale aan die Universiteit van Pretoria gelewer het. As die 'artikel' dan so geweldig invloedryk was, moet die totale historiese konteks in die historiograaf se eie voorgeskrewe sin ewe ernstig geneem word.

Die lesings waarna hy verwys, is nie vir my studente in die Departement Semitiese Tale gelewer nie, maar op uitnodiging van 'n groep studente van die Teologiese Fakulteit (Afdeling B) aan die Universiteit van Pretoria. Sommige van hulle was oudstudente van my wat van tyd tot tyd my lesings in die literêre fakulteit bly bywoon het. Hulle was van mening dat dit wat ek en professor Louw, destyds van die Departement Grieks aan die Universiteit van Pretoria, kon bied, vir die eksegese en prediking van dominees betekenisvol kon wees. Vanselfsprekend was dit 'n uiters sensitiewe saak, om nie te sê plofbaar nie, maar eindelik is ek meegedeel dat alle struikelblokke uit die weg geruim is en ons is uitgenooi om laat op 'n aantal Vrydagoggende 'n reeks lesings aan te bied wat 'nie te akademies' moes wees nie en op die preekmaakpraktyk van dominees toegespits moes wees. Op Vrydagoggend, 25 Maart 1977 het ek om 11:30 in die groot lesingsaal van die Teologiese Fakulteit (Afdeling B), die eerste van my reeks aangebied - onder groot belangstelling van studente uit albei die kerklike fakulteitsafdelings en onder die wakende oog van 'n aantal dosente van die gasheerfakulteit, veral uit die departement waarvan Eduard Reuss byna anderhalfeeu tevore gesê het: 'Theologia practica quae vocatur, nulla est'6. Gesien die herrie wat die uitnodiging voorafgegaan het, was ek baie versigtig. Mense moes oortuig word om krities te dink sonder dat die bootjie en dus die geloof te veel geskud word. In diesen heil'gen Hallen sucht man die Rache nicht. In die loop van die daaropvolgende maande is die versoek, soos dit maar altyd gaan, herhaaldelik geuit dat die materiaal 'op skrif beskikbaar gestel' word sodat die studente nie so hard moes werk aan afskryf nie en beter kon konsentreer. Een student, wat dié jaar sou klaarmaak maar reeds betrokke was by

\footnotetext{
${ }^{6}$ In die eerste stelling van sy Theses theologicae wat hy op 13 Augustus 1829 in die openbaar teenoor al ses professore van die teologiese fakulteit in Straatsburg verdedig het. Vgl Vincent 1990:126.
} 
'n Christelike radiostasie, wou die hele reeks netso laat uitsaai, maar is (on?)gelukkig gekeer deur die voorstel van, meen ek, die destydse doktor en latere professor $\mathrm{H} \mathrm{J} \mathrm{C}$ Pieterse, dat die lesinginhoud aan almal beskikbaar gestel moet word. En so het ek die lesings (wat ek altyd uitskrywe) uit hande gegee met die verstandhouding dat hulle as aparte lesings vir die doel waarvoor hulle opgestel is, in Hervormde Teologiese Studies gepubliseer sou word. Wat was my verbasing groot toe ek eendag die Hervormde Teologiese Studies ontvang (Jaargang 34, Aflewering 1-2, destyds sonder datum gepubliseer, maar die jaar was 1978) en al ses my lesings ongeredigeerd ${ }^{7}$ aaneengeryg onder een opskrif, 'Gedagtes oor gekontroleerde eksegese', daarin vind. Dit wat nou geld as een van die belangrikste en invloedrykste artikels wat ooit in die Suid-Afrikaanse teologiese konteks verskyn het, is dus niks anders nie as die 'input into' (eerder as 'outcome of') populêre lesings op versoek van studente in ongebruikte lesure gelewer. In dié dae was daar geen redakteur in Israel nie; elkeen het gedoen wat reg was in sy oë. Sonder my medewete of goedkeuring is die ses lesings deur ' $n$ sofer of soferim by HTS tot 'n heksateug gekompileer. Min het ek gedroom wat jare later daaroor geskryf sou word, en, hoewel ek vermoedens gehad het oor die wie en waarom van die Zusammensetzmethode, het ek in die lig van die kerkpolitieke beroeringe van die tyd besluit om die saak maar daar te laat. So het my lesings hulle Moses teëgekom.

Die historiese kritiek wat die geskiedskrywer moes gedoen het om sy groot uitspraak te kon maak, sou die nate van die oorspronklike dokumente so onmiskenbaar soos lidtekens uitgewys het. Die openingsinne van die tweede lesing (Loader 1978:1112 ) is kennelik 'n 'Einleitungsformel' en verwys duidelik na die eerste lesing as 'n ander bydrae, waar ek selfs die titel van die vorige bydrae noem en dus nie kon bedoel dat ek tans aan dieselfde dokument skryf nie. Ek probeer ook opsom wat vroeër gelewer is. Dieselfde gebeur verskeie kere in die derde bydrae (Loader 1978:19), en die laaste een se einde kan alleen sin hê as slot vir 'n bespreking van Psalm 8 en nie vir 'n artikel wat alles omvat wat nou daar staan nie. Hoewel dit, anders as die pasgenoemde, nie in die teks self gesien kan word nie en ook nie veel verskil maak nie, is die gepubliseerde volgorde ook anders as dié waarin dit aangebied is: Die lesing op bladsye 35-40 is op 16 September 1977 gelewer en diè op bladsye 26-30 op 23 September 1977.

Hierdie besonderhede is belangrik om die historiese konteks en dus die betekenis van die 'artikel' te bepaal. Ek het gemeen my taak is om in ' $n$ uiters wantrouige en soms selfs vyandige konteks 'n lansie te breek vir kritiese vernuwing in die

\footnotetext{
${ }^{7}$ Behalwe vir die woord 'lesing', wat ek self verander had in 'artikel'. Wel het iemand my naam, wat onder elke aparte bydrae was, geëlimineer en nommers aan die "afdelings" voorsien. Die huidige nommer II het ek oorspronklik vir 'n ander gehoor bedoel (vermoedelik vir die Pretoriase Predikantebroederkring wat op 10 Junie 1977 vergader het), maar vir die reeks aangepas ('n kriptiese inskrywing in my daghoek suggereer dat ek dit op 3 Junie vir die studente gelewer het).
} 
veelal konserwatiewe teologiese omgewing, en juis te probeer hulp bied aan studente wat vertel het hoe verward hulle is. Aan die een kant, het die reëlaars van die lesings gesê, hoor hulle by professor Louw en by die Nuwe-Testamentikus, professor A B du Toit, dat 'die struktuuranalitiese metode' reg is, en aan die ander kant is daar professore wat heftig daarteen te velde trek maar tog nie met argumente oortuig nie. Wie moet hulle nou glo? Hulle het beweer dat hulle nie weet hoe om ordelik met eksegese om te gaan nie. Die eintlike vraag was hoe hulle hulle voete kan vind, of: in beheer/kontrole kan kom van 'n situasie waarmee hulle nie raad weet nie. Vandaar my keuse van die uitdrukking 'gekontroleerde eksegese'. Dit was 'n ongelukkige keuse omdat dit die indruk kon laat ontstaan dat mens net gekontroleerd moet werk om die betekenis van ' $n$ teks te vind. Daarvoor dra ek die verantwoordelikheid, maar hierdie konteks toon dat ek probeer het om studente (en hulle dosente) juis te oortuig dat verabsolutering en die gangbare opvatting dat daar net een 'regte' metode vir eksegese is, vermy moet word, terwyl ek die entoesiastiese skoolvorming rondom die 'nuwe metode' gekritiseer het en gewaarsku het dat name soos 'struktuuranalise' gevaarlik is'. Hiermee kan vergelyk word wat ek geskryf het in die dokument wat as basis vir die lesings gedien het, naamlik die metodologiese verantwoording van my proefskrif. Die volgende staan in die slotparagraaf:

'So 'n metodologie skep dikwels die indruk van 'n aanspraak op finaliteit - dat dit nl die sleutel sou wees waarmee alle probleme matematies opgelos kan word. Die teendeel is egter waar. Ook wanneer gesteun word op die insigte van die moderne linguistiek, bly daar nog groot ruimte vir wetenskaplike aanvoeling en inlewing in die wêreld van die Ou Testament. Heelwat probleme wag nog op 'n antwoord en die onsekerheidsfaktor kan nooit geëlimineer word nie' (Loader 1975:26).

Vergelyk ook verskeie uitsprake van my uit die tagtigerjare:

'Dit kan gebeur dat die metode meganies toegepas word. Ook dit hoef nie te gebeur nie, maar in feite word 'n diskoersanalitiese ontleding dikwels beskou as ' $n$ volledige deurgronding van die teks. ... 'n Diskoersanalise kan nie op sigself 'n outeur se bedoeling ontbloot nie. 'n Reeks sinbetekenisse kan nie so maklik beskou word as die betekenis van 'n literêre eenheid nie' (Loader 1982:97, 1989:132).

\footnotetext{
$\overline{8}$ gl my spot daarmee as 'n modeverskynsel waarvan gepraat moet word as die dogma van sola structura (Loader 1982:82).
} 
Hierdie 'ander' kant van die saak kon nie misverstaan word nie, want ek het dit verduidelik aan die hand van 'n spoedig berug geworde voorbeeld (tandheelkundige oogmerke wat nie met ginekologiese metodes bereik kan word nie as beeld van hoe die keuse van 'n metode deur die oogmerk van die eksegeet bepaal moet word - 'n illustrasie wat ek eers heelwat later gewaag het om in 'n studiegids van Unisa op skrif te stel; vgl Loader 1989:104-133). Daarvan is die neerslag ook in die lesingteks self te lees (Loader 1978:3). Dit is alles van seminale belang vir die padbou-ingenieur, want hy drapeer ' $n$ groot deel van sy geskiedenis om die 'weg' van 'die struktuuranalitiese metode' waarvan ek volgens hom die groot profeet sou geword het. Dit is sekerlik waar dat ek erns met die struktuur of die bou van tekste gemaak het en die studente tegnieke probeer leer het om dieselfde te kon doen. Dit het egter in 'n bepaalde konteks gebeur en is gerelativeer deur die waarskuwings teen imperialisme wat ek sopas vermeld het en wat ek, na my eie mening, ook in my twee boeke uit daardie tyd toegepas het. Ek wil dit nie voorstel asof ek jare gelede identies gedink het aan vandag nie, maar kollega Le Roux ignoreer die werklike gebeure (wie es eigentlich gewesen!) en skilder sy prentjie uit die perspektief van wat later van 'die' struktuuranalitiese metode geword het, 'n ontwikkeling wat hy wil bestry (ek ook). Ek aanvaar verantwoordelikheid vir wat ek gesê het (en ná byna twee dekades sou ek dinge natuurlik nie meer sê soos destyds nie), maar die historiese verband uit die sewentigerjare werp lig op die redes waarom ek destyds soveel klem op verskillende metodefasette gelê het en gepoog het om tot orde by te dra. As dit later gekanoniseer is en as daar essensialistiese beskouings oor 'die regte betekenis' en positiwistiese sekerhede oor meganies agterhaalbare waarhede aan gekoppel is (ek dink dit het wel gebeur), dan moet dit aan die momentum en konteks van die latere gebeure toegeskryf word ${ }^{9}$.

My punt met hierdie betoog is om aan te dui dat professor Le Roux self nalaat wat hy van ander vereis. As hy self in sy geskiedskrywing minder 'teksimmanent' te werk gegaan het en met die historiese agtergrond van sy tekste rekening gehou het, kon dit die beeld wat hy presenteer aanmerklik verander het. Ek het alleen twee voorbeelde van my eie werk genoem omdat dit deur hom self sentraal gestel word. Het hy alleen my werk so 'immanent' gelees of moes ander rolspelers dieselfde lot ondergaan? Omtrent enige antwoord hierop, lyk dit my, sal op kritiek neerkom.

'n Verdere voorbeeld wat in die rigting van konteksverwaarlosing wys, is die feit dat wel heelwat gemaak word van die invloed wat die etiese teologie op my werk

\footnotetext{
$\overline{9} \mathrm{Vgl}_{\mathrm{gl}}$ hoe ek, soos hier, reeds in die vroee tagtigerjare my van die struktuuranalitiese sk(x)l gedistansieer het: 'Daar is ook' $n$ klein groep Ou-Testamentici [dis nou ek] wat wel die waarde van diskoersanalitiese tegnieke aanvaar om die opbou van tekste vas te stel, maar 'n veel kleiner plek aan die metode toeken as wat gangbaar is. Vir hulle [pluralis securitatis] is dit nje 'n manier om tot by die betekenis van 'n teks deur te Jring nie (wat wel oor die algemeen by die diskoersanalitici die geval is), maar eerder om in raamwerk te verskaf waarbinne daar plek is vir ander metodes om die betekenis uit te pluis. $M$ a $w$ dié metode geld as nuttig om een aspek van die teks mee te ondersoek, maar nie as genoegsaam om 'n hele "diskners" te "analiseer" nie. Daarom behoort hierdie groep nie werklik tot die diskoersanalitiese rigting
} 
sou hê (wat ek, met enige reserwe, nou onbesproke laat; vgl Le Roux 1993:300-305), maar nie aandag gegee word aan vergelykbare kontekstualiserings van ander figure wat as vername rolspelers voorgestel word nie. Behalwe 'n paar min of meer insidentele opmerkings is daar byvoorbeeld nie ' $n$ vergelykbare teologiese situering van Deist of Prinsloo nie, en dit terwyl beide vir die outeur oriënteringsfigure is. Deist het persoonlik meermale die invloed van die piëtisme op homself uitgewys en maak dit nie ongereeld kenbaar nie. Eweneens is Prinsloo se konteks as kerklike professor aan 'n gereformeerde instelling en die bekende verdediging van sy metode, naamlik dat dit goed werk vir die opleiding van Nederduitse Gereformeerde predikante, nie van betekenis in die skildering wat Two Ways van hom aanbied nie. Dit is interessant om te spekuleer hoe hulle portrette sou gelyk het as die skrywer sulke kontekstuele verbande uitgewerk het. Wat hy van Prinsloo sê (Le Roux 1993:225), kan ook van homself gesê word: Naturally he makes such remarks, but these are infrequent and do not form the essence of his work. Byvoorbeeld inligting oor Colenso se 'satisfying' liefdeslewe en sy geldsake (Le Roux 1993:93), maar nie oor sy teologiese vorming, agtergronde en tradisie nie. Afgesien van kort opmerkings oor die Afrikaanse teologiese tradisie wat hier en daar deurslaan (bv in verband met die Du Plessis-saak [Le Roux 1993:107] en oor Verhoef [Le Roux 1993:22]), ontmoet ons net tekste van outeurs soos professor Le Roux hulle weergee.

\subsection{Die statiese voorstelling van figure}

Vir 'n geskiedwerk is die skildering van rolspelers merkwaardig plat. Elke rolspeler se begin, voortgang en einde is identies aan daardie karakter. Selfs diegene van wie hy ten opsigte van werk aan die profetiese literatuur toegee dat hulle nie mooi in sy tweepadskema pas nie (Eybers, Van der Merwe, Van Selms en enkele kleindrukfigure; Le Roux 1993:204-216), verdwyn soos hulle gekom het, sonder selfs 'n verandering in hul kostumering. Nie dat 'n geskiedskrywer met karaktertekening besig moet wees nie, maar 'n Ou-Testamentiese gemeenskap waarvan die lede oor drie dekades staties bly, verdien nie 'n geskiedenis nie. Oor Vosloo maak die outeur die opmerking dat hy in sy 'later years' een soort 'non-historical' benadering vir 'n ander verruil het, wat van geen ontwikkeling spreek nie (Le Roux 1993:198).

Al die figure wat uitvoerig aandag ontvang, word voorgestel asof hulle geen ontwikkeling deurgegaan het nie. Dit is kennelik nie waar nie. Enigiemand wat Deist se Historiese heuristiek, teologiese hermeneutiek en Skrifgesag uit 1976 vergelyk met, sê maar, sy 'Heads I win, tails you lose: Yahweh and the editor of the exodus story'

nie' (Loader 1982:93). 
(1989) en sy 'Profete in Israel: 'n probleemstelling' (1990), sal aanmerklike verskille kan aantoon. Deist self het ook verskeie kere na sy eie ontwikkeling verwys, maar niks daarvan kom in die boek na vore nie. Deist is ongetwyfeld tans 'n Ou-Testamentikus van so ' $n$ hoë statuur in Suid-Afrika dat hy meer as uitvoerige opsommings van sy werk en panegiriese lof verdien: 'n histories geloofwaardige beskrywing wat ook aan sy ontwikkeling geregtigheid laat geskied. 'n Statiese Deist is eenvoudig ongeloofwardig. Selfs Prinsloo, wie se werk meer gelyksoortig gebly het, kan ná twee dekades nie beweer אהיה אשר אהיה nie. Hierdie punt het ek ook in een van ons onderhoude met professor Le Roux bespreek, en ek meen die neerslag daarvan is te sien in 'n opmerking wat hy oor my maak:

'It must, however, be noted that the later Loader was much more historically inclined and less interested in structures. Structural analysis served as a kind of "shorthand", indicating how he had mastered the text' (Le Roux 1993:309).

Dit is egter ook net 'n toegewing, van dieselfde aard as die sydelingse opmerking oor my gewraakte lesings van 1977. Die 'shorthand'-idee was vroeg reeds by my teenwoordig (vgl hierbo die instemming van Kaiser) ${ }^{10}$. In my latere werke, sommige waarvan buite die sperdatum val maar waarin professor Le Roux insae gehad het terwyl hy die navorsing vir sy geskiedenis gedoen het, kom daar egter na my eie mening aanmerklike verskille voor wanneer die vroeëre werke vergelyk word. Dit laat ek ter beoordeling aan andere en wys slegs op enkele voorbeelde.

Die outeur deurbreek dikwels sy selfopgelegde terminus ad quem van 1987, waarvan hy ten onregte sê dat hy dit streng gerespekteer het (Le Roux 1993:11, 12) - in Deist se geval ten opsigte van sowat twintig werke, in Prinsloo s'n ten opsigte van dertien (hoewel dit in die bibliografie na meer lyk), en in myne ten opsigte van sewell. Sulke oortredings van sy eie reël word arbitrêr gedoen. Hy het verskeie artikels van Deist uit die negentigerjare bestudeer, in omvang nie veel minder as ' $n$ monografie nie, en van Prinsloo sommer nog 'n paar boeke ook. Oor my eie monografie oor Sodom en Gomorra (met die titel $A$ Tale of nu Cities wat ek by Charles Dickens, no less, afgekyk het; Loader 1990) word egter niks gerep nie. In dié studie bied ek onder andere 'n ondersoek na histories-kritiese perspektiewe op die Pentateugverhaal wat nie

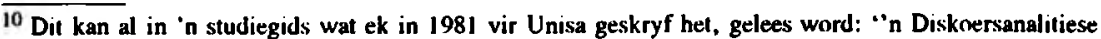
benadering kan nuttig wees as hy eerder die beskeie rol van die bepaling van 'n raamwerk speel. Dan vul hy ander metode-aspekte aan sonder om aangesien te word vir eksegese as sodanig' (Loader 1982:97).

II Dit kom voor of hierdie datumgrens net ' $\mathrm{n}$ gerieflike streep is wat as veiligstelling gebruik kan word om te verantwoord waarom sekere publikasies nie aandag kry nie; dit is 'n grens wat geignoreer kan word wanneer dit die historikus pas.
} 
pas by die beeld wat professor Le Roux van my skilder nie. Hoewel ek probeer aandui hoe aandag aan die struktuur van die teks ' $n$ invalspoort is na historiese ondersoek (à la Kaiser hierbo), is dit na my eie mening (en, dink ek, uit die reaksies op die boek) duidelik dat daar ten spyte van die kontinuiteit een en ander in die kwarteeu sedert my eerste publikasie gebeur het.

Enkele van my resente artikels (Loader 1990 en 1992) kom wel in berekening. Wanneer professor Le Roux 'Seeing God with natural eyes' bespreek ('n referaat wat hy al in 1990 aangehoor en gediskusseer het), merk hy niks nuuts of anders op nie (Le Roux 1993:317-318). Inteendeel, hy het net oog vir dit wat hy dink 'typical' van my is en hy reken dis maar net weer my 'predilection for polar tensions' wat te sien is in die behandeling van transendensie en immanensie in die boek Job. Die groot theologoumenon van die eeue is vir hom 'n blote hebbelikheid wat ek uit Polar structures oorgehou het. Hy sien geen verband tussen wat ek hier betoog en my betoog oor 'Natuur en wysheid' (1990) nie, terwyl hy die perspektief van ander artikels op die onderwerp (waaronder 'Life, wonder and responsibility', Loader 1991) nie eens noem nie. Hy het selektief te werk gegaan met die keuse van dié artikels van my wat hy ter diskussie wil stel en dié wat hy wil verswyg. Die teologiese implikasies hiervan en die verhouding tot my vroeëre werk kom nie by hom op nie, nie eens die vraag of dit denkbaar is langs die pad waarop hy sê dat ek aan die reis is nie. As hy reg is met die $\mathrm{pad} / \mathrm{stroom} / \mathrm{skool}$ waarin hy my plaas, is daar nóg 'n hiaat in sy voorstelling: mens sou ten minste verwag dat hy, in plaas van daaroor te swyg, 'n verklaring sou probeer vind vir die vraag hoe die getuienis van die historiese belangstelling in my werk (vgl o a Loader 1984 en 1990) dan met so 'n eensydig 'immanente' curvit te rym is.

Professor Le Roux stel dit voor asof my hele loopbaan deur die etiese teologie gevorm is en asof my werk aan die wysheidsliteratuur hoegenaamd nie sonder hierdie invloed verstaan kan word nie (Le Roux 1993:300-301). Dié invloed het egter eers in 1982-83 'n rol begin speel. Teen daardie tyd het ek al twee boeke en verskeie artikels oor die wysheidsliteratuur geskryf. Boonop sê die historikus dat hierdie invloed onder andere toegeskryf kan word aan die feit dat ek my eie teologiese wortels in die etiese teologie sou ontdek het. Moeilik verstaanbaar is egter dat sowel dít as die volgende uitspraak waar kan wees: 'Loader's general theological design was very much shaped by Dutch ethical theology' (Le Roux 1993:300). Logies moes ek eers 'n 'general theological design' gehad het waarvan ek die wortels in die etiese teologie kon ontdek het. In elk geval is daar nie in my vroeë werk van hierdie invloed sprake nie. Weer 'n eendimensionele beeld.

'n Soortgelyke vraag aan die een wat ek vroeër gestel het, sou weer aan die bod kon kom: Is monolitiese voorstelling net my lot? 'n Antwoord het ek enkele paragrawe gelede gesuggereer. 
Namate die momentum van my betoog opbou, kan ek bondiger raak. 'Die 'twee weè' is 'n keurslyf waarin alles geforseer word. Natuurlik het hy die reg om hoofstrome te probeer tipeer en selfs om vir sy eie voorkeure op te kom (dis deel van geskiedskrywing), maar die leser het ook die reg om die toereikendheid daarvan te kritiseer. $\mathrm{Na}$ my mening kry professor Le Roux alles slegs teen die prys van ernstige oorvereenvoudiging, veralgemening en selfs negering in sy skema ingepas. Daar is net twee weë, of die een of die ander moet gekies word, alles wat in Suid-Afrika op die gebied van die Ou-Testamentiese wetenskap gedoen is, moet hierin gedruk word.

Ironies bevestig professor Le Roux se eie toegewing oor uitsonderings hierdie oordeel. Wanneer hy in die vierde hoofstuk vir die soveelste keer van sy tweerykeleer vertel, sê hy dat daar eers gou gepraat moet word oor 'n paar figure wat hy nie daar kan inkry nie. '... a few scholars who cannot be fitted into this scheme' (sic!) verraai dat hy daarop uit is om te probeer vakgenote 'ingepas' te kry, dus dat dit sy manier van doen is.

Dit is nie verbasend dat die skrywer se voorstelling nivellerend werk nie. Hy het ' $n$ idee van twee paradigmas, en dié is al wat daar te vinde is. Die histories-kritiese paradigma is aan die 'German scholars' en hul plaaslike vaandeldraer, Deist, te danke. Die 'immanente' paradigma is die ander een en word vanuit die Prinsloo-dampkring geprojekteer op nagenoeg alles wat die skrywer as nie-histories-krities beskou. Goeie illustrasie hiervan is te sien in sy beskrywing en herbeskrywing van die sola structura in die werke van Prinsloo en sy invloedsfeer by sowel die profetiese as psalmiese literaturur (Le Roux 1993:216-232 plus 233-242 en 277-293). Diegene wat min of meer "literêr' werk, hoewel nie volgens die rigiede patroon wat professor Le Roux by Prinsloo identifiseer nie, word ook in die pot gegooi en deur die blote oorweldiging van die skema van twee enkelbaanweë gedwing om dieselfde te wees. Voorbeelde hiervan is die behandeling wat veral Potgieter ontvang (Le Roux 1993:235-242) en die sowat twee bladsye wat aan Burden se literêre werk aan die liedere van Israel gewy word (Le Roux 1993:273 en 275-277). Al maak hy verduidelikende opmerkings soos in die twee gevalle wat pas genoem is, lei dit nie tot billike en genuanseerde uitwerking van die vertakkings, rondritte, sypaaie, voetpaaie en alternatiewe roetes op die vakgebied nie, maar eerder tot minimalisering van enigiets wat kan suggereer dat die tweepadmodel dalk nie so ' $n$ goeie kensketsing van die Suid-Afrikaanse toneel in die hand werk nie. Waarom dié model nou juis so sterk gehandhaaf moet word, is vir my nie duidelik nie. Ons sit juis met figure soos Eybers en Verhoef wat volgens die outeur se eie erkenning nie 
inpas nie en log nie geïgnoreer kan word nie. Hy kon dieselfde bereidheid tot nuansering ten opsigte van ander modaliteite aan die dag gelê het sonder om sy apologie vir die historiese kritiek prys te gee. Die resultaat sou 'n soepeler en lewensgetrouer beeld van die vakgebied gewees het en sy missie (om die historiese kritiek te propageer) juis goed gedoen het. In plaas daarvan dwing hy die 'verwerpers' van die historiese kritiek en die 'immanente lesers' in dieselfde kraal deur hulle te assosieer en die onderskeid dusdoende te nivelleer (vgl die illustrasie van dié tegniek in Le Roux 1993:190, waar hy byvoorbeeld Eybers en Van Dyk saamgooi). Soos dit nou in die boek staan, is sy voorstelling van paradigmas, strominge of paaie, net soos sy portrette van persone, so strak dat selfs al die detail van sy lof en komplimente nie diepte, nuansering of kleur teweeg bring nie.

Ek het reeds die historikus se reg erken om op te kom vir en te verdedig wat hy wil. Apologetiese propaganda, veral in die historiografiese genre, is egter iets kritiseerbaars omdat dit oordrywings en onbillikhede baar. So is dit ook in sy boek. Sy propaganda vir die historiese kritiek word nie alleen gekoppel aan karikaturisering van wat hy as opposisie daarteen beskou nie, maar ook aan vooroordeel in sy beskrywing van Deist se werk. Prinsloo moet dit byvoorbeeld ontgeld dat hy die 'korrekte' eksegese probeer doen, maar wanneer Deist die benadering van Von Rad se teologie die 'korrekte' vind, word hy nie daarvoor gekritiseer nie (Le Roux 1993:159), net voortgeprys. Deist word nooit gekritiseer nie, selfs nie wanneer hy 'n keer, met 'amicable personality' en al, 'harsh' genoem word nie. Wanneer ek my ook met die historiese kritiek besig hou, maak kollega Le Roux dit af as 'n 'addendum' of hy verswyg dit, maar wanneer Deist ook die struktuur van 'n teks ondersoek (vgl Deist 1977), bied hy dit aan as getuienis van gebalanseerdheid (Le Roux 1993:46)12. 'n Ou-Testamentikus van Deist se statuur het nie sulke oorentoesiastiese propaganda nodig nie. Die emosionele taal waarmee Deist se krediete teenoor Antjie Somers se bedreiging geboek word ${ }^{13}$, doen hom geen guns nie.

\section{WIE IN EN WIE UIT IS}

Die kriteria om as leidende figuur behandel te word, is substansiële publikasies, nasionale en internasionale erkenning en invloed op doktorale studente (Le Roux 1993:12), en die datums vir insluiting lê 'strictly' tussen 1957 en 1987. Dit word, soos

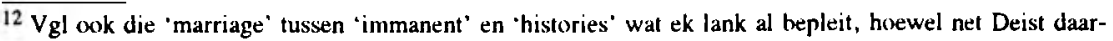
voor krediet kry (Le Roux 1993:55).

${ }^{13}$ Byvoorheeld: 'After the seventies many were caught up in the claws of one method (structural analysis)'(Le Roux 1993:72); 'Deist "saved" these theologians (die 'German critics') from the "immanent onslaught" of the seventies' (Le Roux 1993:157). Vgl ook hoe Van Selms van 'injustice' beskuldig word vir wat 'fair criticism' kan heet (Le Roux 1993:180).
} 
ek bo reeds aangevoer het, nie strictly toegepas nie. Arbitrêre in- en uitsluitings sorg vir groot leemtes in die bock.

Die grootste is die uitsluiting van Berend Gemser (wie se naam, die een keer dat hy genoem word, nog verkeerd gespel word). Hy is waarskynlik die Ou-Testamentikus met die grootste internasionale aansien en die grootste invloed op SuidAfrikaners wat hulle met die Hebreeuse Ou Testament besig gehou het en nog besig hou (Hebreeuse Spraakkuns ${ }^{14}$, Sprüche15, Tekst en Uitleg). Boonop kon hy dit nog netnet in terme van die boek se terminus a quo in 1957 en die stigting van die OuTestamentiese Werkgemeenskap gemaak het. En: Het C J Labuschagne, wat Gemser se Hebrecuse spraakkuns verwerk het, nie genoeg geproduseer om vermeld te word nie? Of tel net die werk wat hy gedoen het voor sy vertrek na Nederland?

Om Colenso uit die vorige eeu ingesluit te kry, word gesê (Le Roux 1993:92) hy is 'just too important to be left out'. As dit die kriterium is, moet Gemser, wat eers in 1957 na Nederland terug is en daarna nog gepubliseer het, ook inkom. Wat is 'important' nou eintlik? Ek kan die vermoede nie onderdruk nie dat Colenso so belangrik is vanweë dit wat in die boek met hom gemaak moet word. Daarom wil die skrywer hom insluit, bladsye van die fynste detail oor sy matematiese berekeninge uit die Pentateug reproduseer en hom aanwend as element in sy oratio pro historia critica. Dieselfde geld ook vir die insluiting van Johannes du Plessis uit die vroeë dekades van hierdie eeu.

Sy insluitingskriteria doen ten spyte van al sy veiligstellings verskeie vakgenote te kort. Verskeie persone word genegeer/vermy en ander word na my mening ernstig onderwaardeer. J J Gluck en Leilah Bronner, die enigste Joodse (en, wat die Boere betref, Engelssprekende) Ou-Testamentici wat gedurende die tersaaklike periode deelgeneem het aan die Werkgemeenskap se bedrywighede en 'n agtenswaardige bydrae gelewer het, word eenvoudig oor die hoof gesien. Hoe ookal oor hul bydrae gedink word, die vraag kan gevra word of die Joodse perspektief nie ook ten minste 'n paragrafie verdien het nie.

Nog 'n weglating wat soos 'n voortand gemis word, is die werk van Itumeleng Mosala, Ou-Testamentikus van Kaapstad. Sy radikale en kritiese gebruik van die Ou Testament in bevrydingsteologiese perspektief is, hoe die historiograaf ook polities daaroor mag oordeel, juis in die situasie wat al in 1987 aan die ontwikkel was, 'just too important to be left out'.

Persone wat ingesluit word ten spyte daarvan dat hulle volgens die outeur self nie eintlik voldoen aan sy kriteria nie ${ }^{16}$, is Heyns, Gous (wie se van ook 'n slag

\footnotetext{
${ }_{14}$ Die eerste druk het vón professor Le Roux se sperstreep verskyn (1953), maar die tweede, verbeterde druk in 1960.

${ }^{15}$ Gemser 1963; saam met die volumes van die serie Tekst en Uitleg wat Gemser geskryf en help uitgee het, word dit nog wyd gebruik.

${ }^{16}$ Die interessante reaksie van kollegas, uitgespreek by kongresse, seminare en elders, wat meen dat
} 
verkeerd gespel word), Potgieter en Van der Merwe (Le Roux 1993:12-13). Dit is egter telkens in gevalle wat hom pas en dus 'n kwessie van 'selection of evidence' (wat onverantwoordbaar is, nie 'convergence of evidence' nie - wat wel verantwoordbaar is ${ }^{17}$ ). Dit is ook merkwaardig dat professor Le Roux, vir wie doktorale studente so belangrik is dat hy hulle tot evalueringskriterium verhef, oral veel maak van die verhouding tussen die werk van promotors en hul promovendi, maar nie vermeld dat Gous 'n promovendus van my was nie. Is dit dalk ook omdat dit hom nie pas nie, maar wel die feit dat Gous met 'n sosiologiese benadering gewerk het? Gous erken wel my invloed (Gous 1987:102-103, vgl Gous 1988; Le Roux 1993:297), maar het iets gelewer wat nie in die tweepadpatroon wil gaan sit nie en bevestig dus nie die prentjie wat die historikus graag wil skilder nie. Gous behoort hom te laat insien het dat sy voorstelling van 'n 'immanente' skool, as dit vir Prinsloo en sy leerlinge opgaan, in elk geval nie oral opgaan nie. Daarbenewens het Prinsloo nie net my invloed ondergaan nie, maar ook daaraan verander, in 'n ander rigting as ek ontwikkel en verskeie kere in lesings en in plaaslike sowel as internasionale tydskrifte van my verskil en selfs teen my gepolemiseer. Een belangrike geval gaan juis oor die hele metodestorie, waar hy beswaar het teen my historiese interpretasie van Pentateugtekste (vgl Loader 1985:14-32, Prinsloo 1985:33-35) - (on)bewustelik(?) deur professor Le Roux geïgnoreer.

Hoewel dit nie streng met insluitingskriteria te doen het nie, wil ek, terwyl ons met die 'invloed' van vakgenote op mekaar te doen het, ook die opmerking maak dat die opvatting van invloed soos dit in die boek voorkom, erg meganies is. Dit lyk asof daarmee ' $n$ alles-of-niks oorname van die woorde van die meester bedoel word, of so funksioneer dit in elk geval. Daar is ook in hierdie opsig nie sprake van nuansering nie. Die skrywer oorweeg nie of iemand wat deur 'n ander beinvloed word ook krities teenoor die bron van die invloed kan staan nie. Ten spyte van wat hy op bladsye 343344 sê, lyk dit nie asof professor Le Roux reken met resiproke invloed nie (wat ook 'n vorm van groei beteken). Weer net 'n strakke beeld van een stel idees wat van leermeester na leerling getradeer word. In die literatuur wat hy aanhaal, is daar egter voorbeelde van hoe die beïnvloede krities teenoor die beïnvloeder staan en op punte distansie neem sodat diskussie moontlik word. Dié sal ek vir ander laat om te soek.

Wat die onderskatte vakgenote betref, wil ek volstaan met die redelik summiere vermelding van gevalle. Dit kan in latere debatte verder gevoer word. Vakgenote wie se bydrae na my mening onderspeel word, is Wittenberg, maar veral Nel en dalk ook, uit die ouer garde, Kroeze (Le Roux 1993:334-343). Nel se bydrae tot ons kennis van die Spreukeboek is van internasionale gehalte en word wel opgesom, maar sy

\footnotetext{
hulle ten onregte uitgelaat is of te min paragrawe/bladsye 'gekry' het, nou daar gelaat.

${ }^{17}$ Professor Le Roux sien 'convergence of evidence' blykbaar aan vir iets anders; vgl Le Roux 1993:310 vir ' $n$ rare definisie daarvan.
} 
betekenis strek verder as dit en verdien ook meer.

Die boek wemel van taal-, spel-, punktuasie- en formuleringsfoute - te veel om te lys, maar, sover ek kan sien, geen enkele ouderwetse setfout nie. Daar is 'is' en 'are' foute, dubbelsinnige formulerings, hier en daar selfs komiese ongelukke (soos die verwysing na 'a member of the Hebrew slaves' in plaas van 'one of the Hebrew slaves' op bladsy 172), woorde wat uitgeval het (bv aan die begin van $d$ op bladsy 67), bywoorde in plaas van byvoeglike naamwoorde (bv 'unsatisfactorily' op bladsy 70), die uitskrywe van etcetera wat, soos Mr en Mrs, nie in Engels konvensioneel is nie, en so aan. Daar is ook tegniese foute (bv my Josef-referaat is in 1974 te Potchefstroom gehou en nie in 1975 by die RAU nie /bladsy 309/; Van Selms se Genesiskommentaar (Van Selms 1967) word met verkeerde bladsynommers aangehaal |bladsy 178|; nóg deel 1 nóg deel 2 van hierdie werk is by Kok in Kampen uitgegee, maar by Callenbach in Nijkerk [bladsy 375] ens). Deist se artikel oor Jesaja 2 is nie in 1966 gepubliseer nie (toe was hy nog besig om te probeer predikant word en Theologia Evangelica het nog nie eens bestaan nie), maar in 1977; die volumenommer is ook nie 2(3) nie, maar 10(2-3) [bladsy 358].

Die ergste aan die taal is egter dat die boek in Engels geskryf is. Ek kan geen rede daarvoor sien nie - ook nie dat die OTWSA as opdraggewer dit aan die skrywer sou opgedring het nie. Hierdie geskiedenis skilder 'n prentjie van die Ou-Testamentiese wetenskap wat in Suid-Afrika feitlik net deur Afrikaanstaliges beoefen is (waarby Gemser en Van Selms ingesluit kan word), wat nie honderd persent waar is nie. Daar word skrams na 'n swart student verwys (Le Roux 1993:274-275), maar verder na geen SuidAfrikaanse siel wat nie Afrikaans kan lees nie (die teenwoordige tyd 'kan' is bedoel om vir die geval Colenso voorsiening te maak).

Dan is daar die uitvoerige Afrikaanse en Nederlandse aanhalings in die boek. Dié is dikwels so geintegreerd met die Engelse teks dat dit sinsteurend is om oor te slaan. Of dit nou die outeur se stille wraak op Old Testament Essays se taalbeleid is of nie - die boek kan nie behoorlik gelees word deur iemand wat nie Afrikaans verstaan nie. Gevolgtrekking: Die boek kan nie in Engels geskryf wees vir die gebruik van diegene wat nie Afrikaans ken nie. Dis 'n boek deur 'n Afrikaner vir Afrikaners oor Afrikaners.

In Beeld van Woensdag, 13 April 1994 skryf die outeur van ons geskiedenis 'n passievolle brief oor die toekoms van Afrikaans as intellektuele taal. Eerstens (Beeld se taalredaksie het dit, soos hulle altyd ten onregte doen, in 'vir eers', wat 'voorlopig' 
beteken, gaan staan en verander), sê hy, is die verengelsing op wetenskaplike gebied "'n vorm van ontmensing'; tweedens, vervolg hy, die 'Afrikaanse wetenskaptradisie (sic, geen s) moet tog eerder gekoester en aangemoedig word'. Dan verset hy hom teen die oorbeklemtoning van 'die strewe na internasionale geloofwaardigheid' en ten slotte kom hy met die oproep: 'Almal wat oor Afrikaans as wetenskapstaal (sic, s) bekommerd is, moet verengelsing met alle vorme van intellektuele verset teenstaan'.

Hoekom het hy dan nie oor Die breẻ en die smal weg geskryf nie? Sou dit onbillik wees om te vra warom hy nie practise wat hy preach nie?

Die hebbelikhede van professor Le Roux ${ }^{18}$, waarvan die oordadige lofprysings die ergste is, kan daartoe lei dat die boek siniese vrae oproep: As alles dan so 'excellent' en 'fine' en 'very important' is, hoe moet dit verstaan word dat sulke deurlugtige geleerdes so agterlik in die historiese kritiek is? Hoekom het hulle die teologiese wêreld en sommer die res van die wêreld nog nie met soveel gawes in orde gebring nie?

Dit bring my by my slotvraag. Nie oor aspekte van my eie werk waarvan ek dink dat ek ernstig misverstaan word en sulke dinge nie, maar oor die bede waarmee die epiloog van die boek sluit. Die geskiedenis eindig treffend met die bekende priesterlike seën as bede vir die Ou-Testamentiese wetenskap, en ek onderskryf dit van harte. Die vraag is egter: Het die beoefening van die Ou-Testamentiese wetenskap in Suid-Afrika 'n verskil gemaak? A N Whitehead (1933:197) het immers gesê die betekenis van bestaan is 'to make a difference'. Het die OTWSA in dié sin betekenisvol bestaan? Gaan dit om God se pad in die wildernis? Lei dié pad êrens heen? Het dit 'n teologiese impak gehad? Indien wel, wat was dit? Dogma verdedig? Nuwe grond gebreek? Dit lyk nie vir my of professor Le Roux dié vraag beantwoord nie. Indien die historikus nie 'n beredeneerde en gemotiveerde betoog kan aanbied waardeur die leser oortuig kan word van die impak en betekenis van die Ou-Testamen-tiese wetenskap nie, is dit baie moeilik om te sê waarom die bedrywighede op dié gebied nie pedanterie was nie. Daarom, dink ek, moet die seënbede dáároor gaan en nie oor die voortsetting van die 'high level of research' waarvoor ons dink dat ons verantwoordelik was nie.

\section{Bibliografie}

Braun, R 1973. Kohelet und die frühhellenistische Popularphilosophie. Berlin: De

${ }^{18} \mathrm{Bv}$ 'so', uitgespreek 'só- 6 ', 'vehemently', 'important', 'wanted to', 'many a' plus enkelvoud, 'extremely', 'very interesting', 'shaped' en andere. 
Gruyter. (BZAW 130.)

Deist, F E 1976. Historiese heuristiek, teologiese hermeneutiek en Skrifgesag. Port Elizabeth: UPE.

Deist, F E 1977. Notes on the structure of Isa 2:2-22. ThEv 10(2-3), 1-6.

Deist, F E 1989. Heads I win, tails you lose: Yahweh and the editor of the exodus story. An historico-esthetic interpretation of Exodus 1-12. OTE 2(3) (NS), 36-52.

Deist, F E 1990. Profete in Israel: 'n probleemstelling. HTS 48(1), $71-84$.

Ellermeier, F 1967. Qoheler: Untersuchungen zum Buche Qohelet I/l. Herzberg: Jungfer.

Frankena, R 1969. Boekbespreking. Nederlands Theologisch Tijdschrift 26(1), 78-80.

Gemser, B 1960. Hebreeuse spraakkuns: vormleer, sinsleer en oefeninge. Pretoria: Van Schaik. Derde, verbeterde druk versorg deur C J Labuschagne (1968).

Gemser, B 1963. Sprüche. Tübingen: Mohr. (HAT 16.)

Gous, I G P 1987. The origin of Lamentations I from a cultural-anthropological perspective. OTE 5 (Old Series), 90-128.

Gous, I G P 1988. Die herkoms van Klaagliedere. DTh-proefskrif, Universiteit van Suid-Afrika, Pretoria.

Kaiser, O 1982. Judentum und Hellenismus. VuF 27(1), 68-88.

Kraus, H-J 1969. Geschichte der historisch-kritischen Erforschung des Alten Testaments von der Reformation bis zur Gegenwart. Neukirchen: Neukirchener.

Le Roux, J H 1993. A story of nwo ways. Thirry years of Old Testament scholarship in South Africa. Pretoria: Verba Vitae. (OTE Supplement Series 2.)

Loader, J A 1975. Aspekte van menslike mag in die Ou Testament. Dissertatie, Rijksuniversiteit Groningen.

Loader, J A 1978. 'Gedagtes oor gekontroleerde eksegese', HTS 34,1-11 + 11-19+ $19-26+26-30+31-35+35-40$.

Loader, J A 1979. Polar structures in the Book of Qohelet. Berlin: De Gruyter. (BZAW 152.)

Loader, J A 1982. Teksimmanente metodes. In Ou Testament. Enigste gids vir OTA30I-U. Pretoria: Unisa, 77-98.

Loader, J A 1989. Teksimmanente metodes. In Scheffler, E H (red), Ou Testament (Honneurs BTh). Enigste Sludiegids vir HOT404-E. Bybelkunde (Honneurs BA). Enigste Studegids vir HBS406-4. (Ou-Testamentiese Eksegese.) Pretoria: Unisa, 104-133 (verwerking van Loader 1982).

Loader, J A 1984. Die Eriese Ou-Testamentici in Nederland tussen 1870 en 1914. DThproefskrif, Universiteit van Suid-Afrika, Pretoria. 
Loader, J A 1985. 'Theologia religionum' from the perspective of Israelite religion - an argument. Missiomalia 13(1), 14-32.

Loader, J A 1990. A Tale of two Cities. Sodom and Gomorrah in the Old Testament, carly Jewish and early Christian traditions. Kampen: Kok-Pharos.

Loader, J A 1990. Natuur en wysheid: een en ander oor die vraag of die wiel herontdek word. OTE 3(2) (NS), 159-170.

Loader, J A 1991. Life, wonder and responsibility: Some thoughts on ecology and Christian mission, Missionalia 19(1), 44-56.

Loader, J A 1992. Seeing God with natural eyes: on Job and nature. OTE 5(3) (NS), 346-360.

Prinsloo, W S 1985. Response to J A Loader, "'Theologia religionum" from the perspective of Israelite religion - an argument', Missionalia 13(1), 33-35.

Ranston, H 1925. Ecclesiastes and the early Greek wisdom literature. London: Epworth.

Van Selms, A 1967. Genesis deel I. Nijkerk: Callenbach. (POT.)

Vincent, J M 1990. Leben und Werk des frühen Eduard Reuss: ein Beitrag zu den geistesgeschichtlichen Voraussetzungen der Bibelkritik in zweiten Viertel des 19. Jahrhunderts, München: Kaiser.

Westermann, C 1966. Das Buch Jesaja Kapirel 40-66. Göttingen: Vandenhoeck \& Ruprecht. (Das Alte Testament Deutsch 19.)

Whitehead, A N [1933] 1967. Adventures of ideas. New York: Free Press. 